cause confusion by naming what might prove to be a described species in a difficult genus which $I$ had not specially studied, I refrained from further describing the perfect insect. Unfortunately, this precaution seems to have been unavailing, for several have written to me for further information on the species; and, as the name has been introduced into published lists of North American Lepidoptera, I have thought it best to prepare the description here submitted, particularly as further study has convinced me that the species here named does not agree with any of the described species of this genus.

Described from 9 specimens ( 3 males and 6 females). Types of both sexes deposited in the U. S. National Museum.

\title{
A NEW GENUS AND SPECIES OF NORTH AMERICAN CHOREUTIN
}

BY PROF. C. H. FERNALD, AMHERST, MASS.

\section{Genus Kearfottia}

Frons smooth and rounded, with the scales inclining downward, not closely appressed, erect on the vertex ; labial palpi ascending, the second segment with more or less separated scales beneath, recalling the genus Choreutis, third segment a little shorter, naked and somewhat pointed; maxillary palpi present; proboscis very short; eyes hemispherical ; ocelli absent; antennæ not quite half the length of the costa, ciliate, the ciliæ nearly as long as the diameter of the shaft; thorax with a small tuft at the end above.

Fore wings subelliptical, nearly three times as long as wide; vein $\mathrm{Ib}$ with a long fork at the base and ending near the outer third of the hind margin; cell about two-thirds of the length of the wing; vein 2 arises before the end of the median, a little further from 3 than that is from 4 ; veins 3 to Io nearly equidistant at the origin; I I arises from the subcostal vein near the end of the first third of the cell ; 7 ends in the outer margin and 8 in the costa; the anterior intercellular vein arises from the subcostal intermediate between the origin of veins Io and I $\mathbf{I}$ and forks near the cross vein, the forks running into 7 and 8 ; the posterior intercellular vein arises at the base of the wing and continues beyond the cell as vein 6 .

Hind wings about half as long as wide, subsemicircular; median vein not pectinate above towards the base; three internal veins, vein $x b$ forked at the base, 2 from near the beginning of the outer third of the 
median vein ; 3 and 4 coalesce and arise from the lower angle of the cell ; 5,6 and 7 nearly equidistant, 7 from the base of the wing; 8 arising free from the base of the wing, running nearly intermediate between the costa and subcostal vein, ends in the costa a little below the apex; cross vein very oblique from the base of 5 till it joins the cellular vein from the base of the wing, then runs up and joins vein 7 a little before the middle.

This genus is more closely related to Choreutis than to any other genus known to me, but is without the metallic scales and some other characteristics of Choreutis. The venation of the fore wing is like that of C. onusta, Walk., but that of the hind wing differs in the course of the upper part of the cross vein and in having a much stronger intercellular vein.

Named in honour of Mr. W. D. Kearfott, who has so successfully begun the study of the North American Microlepidoptera.

Kearfottia albifasciella, n. sp.-Expanse of wings 9 to $10 \mathrm{~mm}$. Head, thorax, base and outer part of fore wing dark brown with bronze reflections; middle of the wing cream-white, with four equidistant dark brown dots on the costal and three on the hind margin of this white fascia; these dots are not present in all the specimens. The dark basal area has a vertical nearly straight outer edge, though there is a slight indentation on the submedian fold. The terminal dark bronzy-brown area which covers about a third of the wing has an oblique wavy inner edge, varying somewhat in the different examples. Fringe concolorous, with a whitish fleck near the anal extremity.

Hind wings and fringes above and beneath, and also the abdomen above, fuscous. Under side of fore wings fuscous, lighter beneath the median fascia. Under side of thorax and abdomen and the legs dull yellowish-white; the fore coxa, femora and tarsi in front and the middle tibia and tarsi in front, dark fuscous.

Described from three specimens, two taken at Plummers's Island, Md, July I893, by Mr. August Busck, and one in Cincinnati, Ohio, July 7, 1903, by Miss Anuette F. Braun. One cotype is in my collection, one in the National Museum, Washington, D. C., and one in the collection of Mr. W. D. Kearfott, Montclair, N. J. 